\title{
Immunologic patterns associated with cure in human American cutaneous leishmaniasis
}

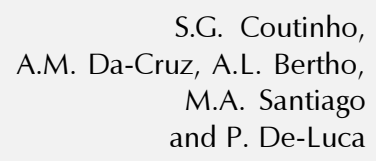

S.G. Coutinho,

A.M. Da-Cruz, A.L. Bertho,

M.A. Santiago

and P. De-Luca

Laboratório de Imunidade Celular e Humoral, Instituto Oswaldo Cruz, FIOCRUZ, Rio de Janeiro, RJ, Brasil
Correspondence

S.G. Coutinho

Laboratório de Imunidade Celular

e Humoral, FIOCRUZ, IOC

Pavilhão Carlos Chagas

Av. Brasil, 4365

21045-900 Rio de Janeiro, RJ

Brasil

Fax: 55 (021) 590-3545

E-mail:

coutinho@gene.dbbm.fiocruz.br

Presented at the International Meeting on Cytokines, Angra dos Reis, RJ, Brasil, November 24-28, 1996.

Research supported by the European Economic Community and CNPq.

Received September 4, 1997 Accepted September 23, 1997

\begin{abstract}
Patients with American cutaneous leishmaniasis were studied before therapy (active lesion) and at the end of therapy (cured patients). Assays of lymphocyte proliferative responses of peripheral blood mononuclear cells induced in vitro by Leishmania braziliensis promastigote antigens (Lb) were performed. Antigen-stimulated cells were harvested for CD4 and CD8 phenotype analysis and the levels of gamma interferon (IFN- $\gamma$ ) and interleukin 4 (IL-4) produced were also determined in the culture supernatants. Two different patterns of Lbinduced $\mathrm{T}$ cell responses were observed: a) predominance of responding $\mathrm{CD}^{+}$cells and mixed type 1 and type 2 cytokine production (IFN$\gamma$ and IL-4) during the active disease, and b) similar proportions of responding $\mathrm{CD}^{+}$and $\mathrm{CD}^{+}$cells, and type 1 cytokine production (presence of IFN- $\gamma$ and very low IL-4) at the end of therapy (healed lesions). This last pattern is probably associated with a beneficial $\mathrm{T}$ cell response.
\end{abstract}
Key words
- Human cutaneous
leishmaniasis
- Leishmania braziliensis
- $\mathrm{CD}^{+}{ }^{+}$and $\mathrm{CD}^{+}$cells
- IFN- $\gamma$
- IL-4

Leishmania are important intracellular protozoan parasites that produce either tegumentary (cutaneous, mucocutaneous, diffuse) or visceral diseases in man in many areas throughout the world. The outcome of infection in each type of leishmaniasis depends on the complex and intriguing interaction of virulence factors and host immunologic responses. It is agreed that the resolution of human infection is dependent primarily on events within the $T$ cell compartment (1-7).

In the mouse model, there is evidence that the mechanisms for cure or resistance to Leishmania major infection are associated with macrophage activation, leading to the destruction of intracellular parasites. Type 1 cytokines such as IFN- $\gamma$ and TNF- $\alpha$ and $-\beta$ when produced by the Th1 subset of $\mathrm{CD}^{+}$ lymphocytes play a pivotal role in this process of macrophage activation and parasite destruction (8-11). On the other hand, the mechanisms for aggravation of the disease in mice are related to the effects of type 2 cytokines such as IL-4, IL-10 and TGF- $\beta$, which are primarily produced by the Th2 subset of $\mathrm{CD}^{+}$lymphocytes as well as other cell types. These cytokines are able to inhibit the differentiation of Th1 $\mathrm{CD}^{+}$lymphocytes and the production of IFN- $\gamma$ and TNF $(8,11$, 12).

$\mathrm{CD}^{+} \mathrm{T}$ lymphocytes also appear to be important in the immunologic mechanisms 
responsible for cure of murine leishmaniasis caused by L. major, L. amazonensis, and L. donovani (13-15). Activated antigen-specific $\mathrm{CD}^{+} \mathrm{T}$ cells have been shown to produce IFN- $\gamma$ and can have a cytolytic effect on parasitized macrophages $(16,17)$.

In humans the most common clinical form of American tegumentary leishmaniasis (ATL) is the localized cutaneous leishmaniasis (LCL) where a single or a few skin ulcers occur with a tendency toward selfhealing or susceptibility to classical antimonial therapy. The scarceness of parasites in the lesions and the presence of hypersensitivity to leishmanial antigens are the main immunoparasitological features of LCL.

Studies from our laboratory (5-7) on LCL patients examined before antimonial therapy (active disease) and at the end of therapy (cure) have shown that the lymphoproliferative responses of peripheral blood mononuclear cells (PBMC) after stimulation in vitro with total L. braziliensis promastigote antigens $(\mathrm{Lb})$, as measured by $\left[{ }^{3} \mathrm{H}\right]$-thymidine incorporation, were not significantly different before and at the end of therapy, although they tended to decline.

The phenotypes of leishmanial antigenreactive $T$ cells stimulated in vitro were also investigated in PBMC cultures. After five days in culture, responding cells were separated by centrifugation over a discontinuous Percoll (Sigma Chemical Co., St. Louis, MO) gradient incubated in the presence of monoclonal antibodies for $\mathrm{CD}^{+}$(T3-RD1, Coulter Immunology, Hialeah, FL), CD4 ${ }^{+}$(T4-FITC, Coulter Immunology) and CD8 ${ }^{+}$(T8-RD1, Coulter Immunology) and finally analyzed by flow cytometry. The supernatant of each culture was also collected and stored at $-70^{\circ} \mathrm{C}$ for later determination of cytokine concentrations.

Comparing the proportions of $\mathrm{CD} 4^{+}$and $\mathrm{CD} 8^{+} \mathrm{L}$. braziliensis-reactive $\mathrm{T}$ cells before therapy (BT) and at the end of therapy (ET) we observed an increase in the percentage of $\mathrm{CD}^{+}$cells $(\mathrm{BT}=23.9 \pm 11.7 \%$; $\mathrm{ET}=42.6 \pm$
$21.7 \% ; \mathrm{P}<0.05)$, a decline in the proportion of $\mathrm{CD}^{+}$cells $(\mathrm{BT}=61.2 \pm 18.3 \%$; $\mathrm{ET}=40.9$ $\pm 21.7 \%$; $\mathrm{P}<0.05$, Mann-Whitney) and a consequent reduction in the $\mathrm{CD}^{+} / \mathrm{CD}^{+}$ratio $(\mathrm{BT}=2.5 ; \mathrm{ET}=0.9)$.

These results suggest that $\mathrm{CD}^{+} \mathrm{T}$ cells may be implicated in the mechanisms of cure of LCL. However, it was not clear whether the process of cure was associated only with the increased percentages of $\mathrm{CD}^{+}$ Leishmania-reactive $\mathrm{T}$ cells or whether it also depended on the balance between $\mathrm{CD}^{+}$ and $\mathrm{CD}^{+}$cells.

The levels of IFN- $\gamma$ and IL-4 production by Leishmania-reactive $T$ cells were also determined by testing the supernatant of antigen-stimulated PBMC cultures. IFN- $\gamma$ was measured by a solid-phase ELISA (Intertest, Genzyme Corporation, Cambridge, MA) and IL-4 was also measured by ELISA (Intertest 4, Genzyme Corporation). The mean levels of IFN- $\gamma$ in supernatants from Leishmaniastimulated cell cultures were $2255 \pm 563 \mathrm{pg} /$ $\mathrm{ml}$ before therapy (active disease) and 3005 $\pm 900 \mathrm{pg} / \mathrm{ml}$ at the end of therapy (cure). The mean levels of IL- 4 on the same occasions were $\mathrm{BT}=415.8 \pm 633.1 \mathrm{pg} / \mathrm{ml}$ and $\mathrm{ET}=$ not detectable. Hence, in association with the $\mathrm{CD}^{+}-\mathrm{CD}^{+}$switch in cured patients we also observed a slight, but not significant increase in IFN- $\gamma$ production at the end of therapy, as well as a highly significant decrease in IL-4 production in cured patients.

In this respect, two different patterns of Lb-induced $\mathrm{T}$ cell responses were detected $(6,7)$ : a) the predominance of a $\mathrm{CD} 4^{+} \mathrm{T}$ cell response with production of a mixed type 1 (IFN- $\gamma$ ) and type 2 (IL-4) cytokine profile during active LCL, and b) similar proportions of responding $\mathrm{CD} 4^{+}$and $\mathrm{CD} 8^{+} \mathrm{T}$ cells, with production of IFN- $\gamma$ and absence of IL4 in cured patients (after therapy). This last pattern characterizes an apparently beneficial $\mathrm{T}$ cell response.

The lymphokine profiles determined in the skin lesions of active cases of ATL (18) have also shown a mixture of type 1 and type 
2 lymphokines with relative predominance of mRNA for type 1 lymphokines.

At least three hypotheses can be advanced to explain the immunological changes observed after therapy: a) the observed decrease in the proportion of Lb-reactive $\mathrm{CD}^{+}$ cells, associated with production of IFN- $\gamma$ but not IL-4 in cured patients, may point to a better modulation of the $\mathrm{T}$ cell-mediated immune responses after destruction of parasites by antimony therapy and the decrease in parasite load. We may speculate that differences in parasite antigens found in active vs healing lesions would be relevant in the mechanisms for differential $\mathrm{T}$ cell activation; in addition, a reduction of parasite load by antimonial therapy may alter the $T$ cell responses to $\mathrm{Lb}$ antigens. Moreover, results from our laboratory (19) on vaccination of human volunteers with a crude promastigote leishmanial vaccine have shown that the majority of the Leishmania-responding $\mathrm{T}$ cells in assays of the lymphoproliferative response to the parasite antigen presented a $\mathrm{CD}^{+}$phenotype and IFN- $\gamma$ production. In this case the $\mathrm{CD}^{+} \mathrm{T}$ cell response seems to be involved in the mechanisms of protective immunity since there is evidence that the vaccine is able to induce protection in approximately $50 \%$ of cases (20). b) $\mathrm{CD}^{+} \mathrm{T}$ cells may play an important role in the cure of leishmaniasis by producing type 1 lymphokines, leading to the activation of macrophages for parasite destruction. c) There is also evidence that $\mathrm{CD} 8^{+} \mathrm{T}$ cells have a cytotoxic effect on parasitized macrophages, with a beneficial effect on the course of the disease (17).

Finally, this observed immunologic pattern associated with cure and/or protection in LCL can be helpful in determining the prognosis of active disease and as an important parameter for the selection of an antigen candidate for a future vaccine.

\section{References}

1. Castés M, Agnelli A \& Rondon AJ (1984). Mechanisms associated with immunoregulation in human American cutaneous leishmaniasis. Clinical and Experimental Immunology, 57: 279-286.

2. Carvalho EM, Johnson WD, Barreto $E$, Marsden PD, Costa JLM, Reed S \& Rocha $H$ (1985). Cell mediated immunity in American cutaneous and mucosal leishmaniasis. Journal of Immunology, 135: 4144-4148.

3. Coutinho SG, Pirmez C, Mendonça SCF, Conceição-Silva F \& Dórea RCC (1987). Pathogenesis and immunopathology of leishmaniasis. Memórias do Instituto Oswaldo Cruz, 82 (Suppl 1): 214-228.

4. Conceição-Silva F, Dórea RCC, Pirmez C, Schubach A \& Coutinho SG (1990). Quantitative study of Leishmania braziliensis braziliensis reactive $T$ cells in peripheral blood and in the lesions of patients with American cutaneous leishmaniasis. Clinical and Experimental Immunology, 79: 221-226.

5. Da-Cruz AM, Conceição-Silva F, Bertho AL \& Coutinho SG (1994). Leishmania reactive $\mathrm{CD}^{+}$and $\mathrm{CD}^{+} \mathrm{T}$ cells associ- ated with cure of human cutaneous leishmaniasis. Infection and Immunity, 62: 2614-2618.

6. Coutinho SG, Da Cruz AM, Oliveira MP, Mendonça SCF, Bertho AL \& De Luca PM (1996). CD4+ and CD8 ${ }^{+}$T cell immune responses of immunocompetent and immunocompromised (AIDS) patients with American tegumentary leishmaniasis. Memórias do Instituto Oswaldo Cruz, 91: 381-384.

7. Coutinho SG, Oliveira MP, Da-Cruz AM, De Luca PM, Mendonça SCF, Bertho AL, Soong L \& McMahon-Pratt D (1996). Tcell responsiveness of American cutaneous leishmaniasis patients to purified Leishmania pifanoi amastigote antigens and Leishmania braziliensis promastigote antigens. Immunologic patterns associated with cure. Experimental Parasitology, 84: 144-155.

8. Heinzel FP, Sadick MD, Mutha SS \& Locksley RM (1991). Production of interferon-gamma, interleukin-2, interleukin-4 and interleukin- 10 by $\mathrm{CD} 4^{+}$lymphocytes in vivo during healing and progressive murine leishmaniasis. Proceedings of the
National Academy of Sciences, USA, 88: 7011-7015.

9. Scott $P$ (1991). Host and parasite factors regulating the development of $\mathrm{CD} 4^{+}$subsets in experimental cutaneous leishmaniasis. Research in Immunology, 142: 32-36.

10. Coffman RL, Chaletalin R, Leal LMCC \& Varkila K (1991). Leishmania major infection in mice: a model system for the study of $\mathrm{CD} 4{ }^{+} \mathrm{T}$-cell subset differentiation. Research in Immunology, 142: 36-40.

11. Liew FY \& O'Donnell CA (1993). Immunology of leishmaniasis. Advances in Parasitology, 32: 161-259.

12. Barral A, Barral-Netto $M$, Yong EC, Brownell CE, Twardzik DR \& Reed SG (1993). Transforming growth factor $B$ as a virulence mechanism for Leishmania braziliensis. Proceedings of the National Academy of Sciences, USA, 90: 3442-3446.

13. Titus RG, Milon G, Marchal G, Vassalli P, Cerottini JC \& Louis JA (1987). Involvement of specific Lyt-2+ $\mathrm{T}$ cells in the immunological control of experimentally induced murine cutaneous leishmaniasis. European Journal of Immunology, 17: 1429-1433. 
14. Hill JO, Awwad M \& North RJ (1989). Elimination of $\mathrm{CD}^{+}{ }^{+}$suppressor $\mathrm{T}$ cells from susceptible BALB/C mice releases $\mathrm{CD}^{+}{ }^{+} \mathrm{T}$ lymphocytes to mediate protective immunity against Leishmania. Journal of Experimental Medicine, 169: 18191827.

15. Chan MMY (1993). T cell response in murine Leishmania mexicana amazonensis infection: production of interferon- $\gamma$ by $\mathrm{CD}^{+}$cells. European Journal of $1 \mathrm{mmu}$ nology, 23: 1181-1184.

16. Muller I, Kropf P, Etges RJ \& Louis JA (1993). Gamma interferon response in secondary Leishmania major infection: role of CD8+ T cells. Infection and Immu- nity, 61: 3730-3738.

17. Conceição-Silva F, Perlaza BL, Louis JA \& Romero P (1994). Leishmania major infection in mice primes for specific major histocompatibility complex class I-restricted $\mathrm{CD}^{+}$cytotoxic $\mathrm{T}$ cell responses. European Journal of Immunology, 24: 2813-2817.

18. Pirmez C, Yamamura M, Uyemura K, Paes-Oliveira M, Conceição-Silva $F$ \& Modlin RL (1993). Cytokine patterns in the pathogenesis of human leishmaniasis. Journal of Clinical Investigation, 91: 1390-1395.

19. Mendonça SCF, De Luca P, Mayrink W, Reston T, Conceição-Silva F, Da-Cruz AM,
Bertho AL, Costa CA, Genaro O, Toledo VPCP \& Coutinho SG (1995). Characterization of human T lymphocyte-mediated immune responses induced by a vaccine against American tegumentary leishmaniasis. American Journal of Tropical Medicine and Hygiene, 53: 195-201.

20. Antunes CMF, Mayrink W, Magalhães PA Costa CA, Melo MN, Dias M, Michalick MSM, Williams P, Oliveira Lima A, Vieira JBF \& Schettini PM (1986). Controlled field trials of a vaccine against New World cutaneous leishmaniasis. International Journal of Epidemiology, 15: 572-580. 